\title{
Insecticidal Resistance of Okra Fruit Borer (Earias vittella) and its Management
}

\author{
Das Ratan $^{1 *}$, Deb Prahlad ${ }^{1}$, Himanshu Pandey ${ }^{2}$ and Moutushi Sarkar ${ }^{3}$ \\ ${ }^{1}$ Department of Horticulture and Postharvest Technology, Institute of Agriculture, \\ Visva-Bharati, Sriniketan- 731236, WB, India \\ ${ }^{2}$ Department of Biotechnology, Dr. Yashwant Singh Parmar University of Horticulture and \\ Forestry, Nauni, Solan, Himachal Pradesh 173230, India \\ ${ }^{3}$ Department of Genetics and Plant Breeding BCKV, West Bengal, 741252, India \\ *Corresponding author
}

\section{A B S T R A C T}

\begin{tabular}{|c|}
\hline Keywords \\
\hline $\begin{array}{l}\text { Earias vittella, } \\
\text { Insecticidal } \\
\text { resistance } \\
\text { mechanism, } \\
\text { Okra fruit borer. }\end{array}$ \\
\hline Article Info \\
\hline $\begin{array}{l}\text { Accepted: } \\
\text { 26 May } 2017 \\
\text { Available Online: } \\
\text { 10 June } 2017\end{array}$ \\
\hline
\end{tabular}

Insect pest is one of the major Earias vittella is one of the important pest of okra and its management is also difficult for its insecticidal resistance mechanism though few chemical and bioagent are effective against fruit borer. Insecticidal like quinalphos, monocrotophos, fenvalerate, deltamethrin, Flubendiamide etc. are effective to manage this insect. Combination of these insecticides is also effective and also able to overcome Insecticidal resistance mechanism. Few biological agent like Trichogram machllonis, T. brasiliensis etc. also identified as an effective control measure against this pest. But Insecticidal resistance is a bottleneck for its management. Many resistance mechanisms like metabolic resistance, nonmetabolic, GST, EST etc. play an important role for its resistance behaviour. However many technique like log dose probit (hlp) assays, dry film technique etc. are being used to identify Insecticidal resistance in Earias vittella.

\section{Introduction}

Vegetables constitute as one of the important component of our food calander, supplying carbohydrates, vitamins and minerals needed for a balanced diet. Among the vegetables grown in India, okra (Abelomoschus esculentus L. Moench.) also known as lady's finger is an important crop grown throughout the year. Though okra finds its origin in South-Africa still India stands top in area and production because of favorable climatic condition. It is grown on an area of 5.33lakh hectare with an annual production 6.34 lakh tons and productivity of 11.9ton per hectare (NHB, 2014). Okra is an economically important vegetable crop which accounts for $21 \%$ of total exchange earnings from export of vegetables from India. Insect pests are the major constraint to production of this important export oriented crop.

Several insect pests reducing its fruit yield, the shoot and fruit borer is the most devastating pest and mainly responsible for causing direct damage to tender fruits about 
$57 \%$ fruit infestation and $23-54 \%$ net yield loss in okra. E. vittella is cosmopolitan species and has been reported on okra and cotton growing areas of the country. It is reported to be more serious in Karnataka, Madhya Pradesh, Gujarat and Maharashtra, where moderate climatic conditions make it breed (Brar et al., 2004).

E. vittella being devastating pest of okra with high damage potential, its suppression becomes inevitable. Use of various chemical insecticides belonging to different classes is in vogue for suppression of this pest but only partial control of this pest could be achieved. indiscriminate and extensive use of these insecticides since past few decades have led to many serious problems like development of insecticide resistance, Resurgence of minor pests, destruction of natural enemies and environmental pollution (Mahapatro and Gupta, 1998).

Though many non-chemical control strategies have been developed under the IPM umbrella, still farmers like to use synthetic chemical insecticides. Due to which E. vitella has developed resistance against the conventional insecticides making it difficult to control (Kranthi et al., 2002). After the era of indiscriminate use of synthetic pesticides, inundative release of biotic agents as a means of pest management subsequent to their mass production on a commercial scale has become very popular. Trichogramma is one of the impotent bioagent that is extensively exploited for successful management of lepidopteran.

Resistant of pest species exhibit various resistance mechanisms like enhanced metabolism of insecticides mediated by higher titres of detoxifying enzymes, reduced cuticular penetration, reduced sensitivity or altered target sites and behavioural mechanisms (Scott, 1991). The same mechanism of resistance may not always be responsible for populations of pest species even against the same insecticide. Therefore, it is very important to understand the basic mechanisms of resistance present in different species of insect pest against a particular insecticide or group of insecticides. Very complicated resistance mechanisms are exist in Earias vittella, but the most important ones is metabolic mechanism. Esterases, glutathione S-transferases and mixed-function oxidases are the most important detoxifying enzymes in the insecticide resistance caused by metabolic factors (Hung et al., 1990).

\section{Materials and Methods}

\section{Biology and economic importance of okra fruit borer}

The genus Earias includes the old world species Earias vitella (Fabricius) (Lepidoptera: Noctuidae) 'which is generally considered to be the most important species within the group, E. vitella. This insect pest is also found on some of the members of malvaceac family.

The pest status of a particular insect depends on its ability to breed on host plants, cornparative growth rate, fecundity, population dynarnics and distribution. The spotted bollwonns, E. vitella (Fab.) and E. insulana (Boisd.) are polyfagaous preferences for various host plants and they are known to attack 38 plant Species. However, the preferred hosts have a great influence on oviposition. fecundity, developlnental period and adult longevity (Hiremath, 2004).On the other hand, different components of the environment particularly temperature and relative humidity determined theinsects metabolism and susceptibility to insecticides (Ananthkrishnan, 1999). Earias vittellalay spherical eggs, about $0.5 \mathrm{~mm}$ in diameter, light bluish green in colour, with ridges. A female 
lays on an average 400 eggs, incubation, larval and pupal period lasts for 3-9, 9-20, and 18-12 days respectively. Single life cycle takes about 22-25 days extending up to 74 days during winter. On hatching, larvae enter fruits and feed on inner contents, the borer is reported to cause about $57 \%$ fruit infestation and 23-54\% net yield loss in okra (Brar et al., 1994).

\section{Determination of insecticide resistance in Earias vittella}

It is most importent to understand the insecticidal resistance mechanism of any insect to develop strategic plan to manage them.

\section{Insecticide resistance status in India}

Nearly $50 \%$ of the total national insecticides consumed are being consumed by cotton crop alone with only $5 \%$ of the total cropping area in the country (Ghosh, 2001). Conventional insect pest control strategies are depends majorly on chemical insecticides. Due to heavy use of chemical insecticide many insect species developing resistance to insecticides.

\section{Insecticide resistance in Earias vittella}

Pesticide resistance is emerging as one of the key constraints to successful crop protection and public health problems worldwide (Dover and Croft, 1984). Although the resistance is a natural mechanism for survival but its development has been accelerated in recent year due to excessive use of chemical pesticides. Insecticides resistance especially to pyrethroids in Earias vittella is now common in many okra growing countries. Resistance may create a serious problem crop production and protection. It is therefore, necessary to undertake further studies towards recognition and monitoring of resistance in Earias vittella and other insects that are exposed very frequently with insecticides. Kranthi et al., (2002) mansion that in recent days, E. vittella the borer has developed resistance against many basic insecticides which makes it difficult to control. Since the produce is harvested at short intervals and consumed fresh in many cases.

Low resistance indicates no problems with field efficacy. Moderate resistance can cause field efficacyproblems just after 1-2 applications of the insecticide in the region (Kranthi, 2005).

It has been observed that fenvalerate $(500 \mathrm{~g}$ a. i./ha) sprayed five times at 15 days intervals starting from 30 days after transplanting could record significantly lower incidence of $E$. vittella compared to endosulfan $35 \mathrm{EC}$ (525 g a. i./ha) (Brar et al., 1994)

Saini et al., (1989) used dry film technique to study the development of resistance in Earias vittella againest fenvalerate and cypermethrin. Results indicate that insect developed 7.8-fold resistance against cypermethrin, whereas no resistance was observed for fenvelerate. Saini and Chopra, 1988, observed differential response in Monitoring of insecticide resistance in field population of E. vittella revealed. They reported that two populations from northern India showed high resistance, > 70.0-fold resistance to cypermrthrin. So it may be concluded that cypermrthrin $E$. vittellahas developed the resistance macanisom againest cypermrthrin. Again In a susceptibility study in field colonies of $E$. insulana revealed that the LC50 of fenvalerate against colony of E. insldana was 1.5. However later fenvalerate was replaced by its active isomer, esfenvalerate and no difference was observed (Hirano et al., 1993).

In a log dose probit (hlp) assays on E. vittella population reflacts that LD50 of cypermethrin, endosulfan, quinalphos, 
chlorpyriphos and carbaryl to be 0.025 , $2.121,0.190,0.112$ and $0.669 \mu \mathrm{g} / \mathrm{larva}$ indicating 3.12, $0.95,1.72$ and 1.24 fold resistance to cypermethrin, endosulfan, quinalphos and chlorpyriphos, respectively. It also reported that E. vitella population from Akola is resistant to cypermethrin, quinalphos and chlorpyriphos as compared to endosulfan. So endosaulfan would be an effactive chemical to manage the same, though moliqule endosaulfan is no longer in use.Akola strain was comparatively more resistant to many insecticides except quinalphos when compared with Amravati, Washim and Nagpur strains. But quinalphos was not vey effactive on Washim strain as they exibite more resistant over the same (7.55 to 12.66-fold) (Satpute et al., 2003).

Mushtaq and Iqbal, (2009) reported that Resistance label of $E$. vittella field population were very low to low levels againest organophosphorous chlorpyrifos, profenophos, triazophos and phoxim. Again E. vittella had no or very low resistance againest new moliquils like spinosad, emamectin benzoate and methoxyfenzoide, a very low to low resistance to abamectin. A very low to moderate resistance to indoxacarb and a moderate resistance to chlorfenapyr. In follow up studies it was further reported that oxidases, which provided resistance by degradation of pyrethroids in resistant individuals, also activate triazophos in its toxic oxon form resulting in a negative crossresistance (Martin et al., 2003) (Table 1).

\section{Metabolic resistance mechanisms}

According to Kitturmath, 2008, increased enzymatic detoxification is the most common insecticide resistance mechanism in insects. In insects the most common type of metabolic resistance is MFO (Mixed-Function Oxidase) mediated resistance (Scott, 1991), though EST (and GST (glutathione S-transferases) are also equally important. Three major detoxifying enzymes, viz., esterases (EST), MFO and GST were found to be involved in the metabolic detoxification of insecticides in many lepidopteran insects (Hung et al., 1990). Many Earias trains exhibit both metabolic and non-metabolic mechanisms of resistance against different classes of insecticides.

The non-metabolic resistance mechanisms exhibited by Earias include reduced sensitivity of target sites, behavioural resistance (Moore et al., 1989) and reduced cuticular penetration of insecticides (Motoyama et al., 1992).

\section{Resistance associated with glutathione-S- transferases}

Detoxifying glutathione S-transferases (GST) are a family of enzymes that catalyze the conjugation of glutathione with electrophilic substrates including insecticides (Soderlund, 1997). These enzymes metabolise insecticides by facilitating their reductive dehydrochlorination or by conjugation reactions (O-dealkylation and O-dearylation) with reduced glutathione to produce watersoluble metabolites that are more rapidly excreted.

According to Vontas et al., (2002), selection of a laboratory colony of the E. vittella againest permethrin and cyhalothrin increased its resistance to both insecticides. Studies with specific insecticide synergists have also shown involvement of GSTase in resistance to OP insecticides. Cheng et al., (1992) observed synergistic effect of tridiphane (TDP), an inhibitor of enzymatic conjugation of insecticides with GSTase on mevinphos, profenofos, quinalphos, methidathion, phenthoate and parathion suggesting involvement of GSTase in the metabolism of OP insecticides in OP-resistant populations with higher GSTase activity. 


\section{Resistance associated with esterases (EST)}

Esterases are frequently involved in the resistance of insects against organophosphates, carbamates, pyrethroids and neonicotinoids. Maa et al., (1990) reported that membranous esterases activities of malathion-resistant larvae were about twice then the susceptible larvae. It also reported that higher esterase activity conferred a major part of the resistance to permethrin and other primary alcohol ester pyrethroids. On the other hand $\mathrm{Li}$ et al., (1998) observed same activity of carboxylesterase in the resistant strain and susceptible strain.

\section{Resistance associated with mixed-function oxidases}

Wilkinson (1983) indicated some characteristics of that make them specially adapted for general purpose protection in herbivorous insects. Microsomal monooxygenases shows a remarkable degree of non-specificity for lipophilic xenobiotics. The enzymes are located primarily in the gut tissue. They are induced by a wide variety of foreign compounds and the presence of the enzymes in the tissues is synchronized with periods of maximum chemical compound exposure. It also observed that The chewing insects have high lavel of microtonal monooxygenase activity then the sucking insects. MFO activity was significantly correlated with that of the methamidophos resistance in the decline stage, i.e., 9 generations after withdrawal of selection pressure. Microsomal mixed-function oxidases (MFO) are capable of metabolizing insecticides with a seemingly endless array of chemical specificities. Because of this, they represent possibly the major detoxification mechanism available to insects when exposed to a chemical compound. The oxidative metabolism mediated by microsomal oxidases is concederded to be a major factor in resistance macanisom againest organophosphates, cabamates, pyrethroids and neonicotinoids (Puniean et al., 2009).

\section{Results and Discussion}

\section{Management of Earias vittella on okra}

\section{Chemicals used for controlling $E$. vittella}

Management of any insect pest is always a challenge. E. vittella, being an important pest of okra it's very important to manage the same scientifically and effectively. Integrated management of E. vittella is very effective rather than chemical, biological or cultural management alone.

Significant reduction of fruit borer infestation was after 3 weeks of final treatment with acetamiprid $20 \mathrm{SP}$ at $50 \mathrm{~g}$ a.i/ha, acephate 75 WSP $333 \mathrm{~g}$ a.i/ ha, imidacloprid $17.8 \mathrm{SL}$ at $100 \mathrm{ml}$, profenofos $50 \mathrm{EC}$ at $1500 \mathrm{ml} / \mathrm{ha}$ resulting in infestation levels of $12.42,14.25$, 15.36 and $15.70 \%$ respectively compared with the control (44.26\%). Manjanaik et al., (2002) reported endosulfan (0.05\%), carbaryl $(0.10 \%)$, monocrotophos $(0.05 \%)$, quinalphos $(0.03 \%)$, dimethoate $(0.05 \%)$, chloropyriphos $(0.04 \%)$, and triazophos $(0.03 \%)$ as effective controlling fruit damage by $E$. vittella on okra with endosulfan $(0.05 \%)$ recording the lowest per cent fruit damage $(2.92 \%)$ and highest fruit yield of $6185.33 \mathrm{~kg} / \mathrm{ha}$. Singh, (2001) also found that endosulfan, quinalphos, phosphamidon, cypermethrin and fenvalerate were effective in controlling of shoot borer of okra E. vittella.Bhargava et al., (2001) fobserved that quinalphos and endosulfan at $500 \mathrm{~g} \mathrm{a}$.i/ha gave superior protection against fruit borer and jassids in okra. Das et al., (2000) observed efficacy of imidacloprid, acetamiprid, acephate and profenofos against the fruit borer, E. vittella on okra and observed that there was reduction in borer infestation to the extent of $15.36,12.42,14.25$ 
and $15.70 \%$ after 3 weeks of spray with the respective insecticide against $44.26 \%$ infestation in control.

Emamectin benzoate @ 8.50 g.a.i/ha recorded lower fruit damage and higher fruit yield and found to be highly promising insecticide against okra fruit borer complex (Bheemanna et al., 2005).Indoxacarb is a very promising insecticide in many lepidopteran and in case of E. vitella a dose of $75 \mathrm{~g} . \mathrm{a} . \mathrm{i} / \mathrm{ha}$ showed maximum reduction $(78.6 \%)$ of population after five days of second spray which was significantly superior over all other treatments and Lamda cyhalothrin @ 50g.a.i/ha also resulted on high reduction of pest population $(71.2 \%)$ and it was statistically on par with the result obtained with Indaxacarb @ 50 g.a.i/ha, Alpha cypermethrin @ 25 and 20g.a.i/ha. Endosulfan @ 500g.a.i/ha was found to be least effective against okra fruit borer by (Sharma and Bhati, 2008). Sarkar and Nath (1989) evaluated eight insecticides against the fruit borer, E. vittella, at Agartala (Tripura) and found that fenvalerate at 0.5 $\mathrm{ml} /$ litre and 750 litres/ha gave the highest reduction in number of infested fruits.
Raj (1985) revealed from field trials conducted in New Delhi that fruit borer of okra was effectively managed by the application of deltamethrin $(0.0065 \%)$. Field experiments conducted at Kanpur (Uttar Pradesh) indicated that malathion $(0.03 \%, 3$ sprays) gave satisfactory protection against okra shoot and fruit borer infestation (Verma, 1985).Lowest damaged of fruits was recorded from dimethoate treated plots followed by profenophos and neem (Supriya et al., 2009).At Varanasi (Uttar Pradesh), 2 applications of malathion (1000 $\mathrm{ml} / \mathrm{ha})$ on okra gave satisfactory reduction of E. vittella (Konar and Rai, 1990).

Four sprays of cypermethrin 25 EC $(0.0075 \%)$ at an interval of 10 days starting from flowering were found effective in reducing infestation of okra fruits by $E$. vittella at Rahuri in Maharashtra (Patil et al., 2002). According to Gupta and Mjshra (2006), monocrotophos gave only low to moderate level of protection to okra crop against $E$. vittella in field experiments conducted in Bihar.

Table.1 Summary of insecticide resistance profile of Earias vittella

\begin{tabular}{|l|l|l|c|c|}
\hline Insecticide Group & \multicolumn{1}{|c|}{ Insecticide } & \multicolumn{1}{|c|}{ North } & Central & South \\
\hline Pyrethroid & Cypermethrin/ & Moderate & Low & Low \\
& Fenvelerate & & & \\
\hline Organophosphate & Quinolphos & Low & Low & Low \\
& Chlorpyriphos & Moderate & Low & Low \\
& Monocrotophos & Low & Low & Low \\
\hline Carbamate & Thiodicarb & Moderate & Low & Low \\
& Methomyl & Moderate & Low & Low \\
& & & Low & Low \\
\hline Cyclodiene & Endosulfan & Low & Low & Low \\
\hline Spinosyns & Spinosad & Low & Low & Low \\
& Emamectin & Low & Low & Low \\
\hline
\end{tabular}


Table.2 Parasitoids of Earias spp

\begin{tabular}{|l|c|l|}
\hline \multicolumn{1}{|c|}{ Trichogramma species } & State where recorded & \multicolumn{1}{|c|}{ References } \\
\hline Trichogramma sp. & Tamilnadu & Cherian and Margabandha (1943) \\
\hline Trichogramma achaeae & $\begin{array}{c}\text { Punjab } \\
\text { Bangalore } \\
\text { Gujarat }\end{array}$ & $\begin{array}{l}\text { Nagana Goud and Thontadarya } \\
(1984)\end{array}$ \\
\hline T. chilonis Ishii & $\begin{array}{c}\text { Punjab } \\
\text { Bangalore } \\
\text { Gujarat }\end{array}$ & $\begin{array}{l}\text { Nagana Goud and Thontadarya } \\
(1984)\end{array}$ \\
\hline $\begin{array}{l}\text { T. chilotraeae } \\
\text { Nagaraja and Nagarkatti }\end{array}$ & $\begin{array}{l}\text { Gujarat } \\
\text { Punjab }\end{array}$ & Manjunath (1974) \\
\hline T. evanescens Westwood & Punjab & Hussain and Mathur (1924) \\
\hline $\begin{array}{l}\text { Trichogrammatoidea near } \\
\text { guamensis } \text { Nagaraja }\end{array}$ & Punjab & Maninder et al., (1983) \\
\hline
\end{tabular}

Combination of insecticide is always a good strategy for management of insect pest and also helpful to overcome the insecticidal resistance. Application of chloropyriphos 20 EC and cypermethrin $3 \mathrm{EC}+$ quinalphos $20 \mathrm{EC}$ gave lowest fruit damage of $18.86 \%$ and $19.97 \%$ and lowest number of bored holes per fruit of $1.17 \%$ and $1.19 \%$ respectively on okra (Papal et al., 2009). Papal et al., (2010) have shown chloropyrifos to be most effective followed by ready mixture of cypermethrin and quinalphos, endosulfan and ready mixture chlorpyrifos along wiht $\alpha$-cypermethrin in controlling the fruit borer, E. vittella in okra. Again Sinha et al., (2009) sujested that bifenthrin, indoxacarb, thiamethoxam, chlorpyrifos + cypermethrin and fipronil were highly effective against $E$. vittella of okra. Nauen et al., (2007) reported that flubendiamide is a new chemical option for control of multi-resistant noctuid lepidopteran pests and an excellent choice in resistant management strategies for lepidopteran pests in general.

In the other hand, very few insecticidal molecule are safe for the natural enemy for the targeted insect hence IPM in this case is not so fusible. But few chemical been identified to be safe for the many natural enemy. Tang et al., (2008) observed that Flubendiamide, a diamide insecticide has a unique chemical structure and a novel mode of action shows excellent efficacy, a broad insecticidal spectrum against lepidopteran insect pests but very safe for the beneficial arthropods and natural enemies. No cross-resistance to existing insecticides. Flubendiamide, first practical synthetic insecticide with a mode of action as an activator of ryanodine receptors with high and spacific activity against lepidopteran insect pests. It has been reported as very effective in the field with highly safe against non-target organisms (Tohinshi et al., 2010). So all those chemicals are very effactive in IPM.

Biocontrol agents + insecticides used for controlling $\boldsymbol{E}$. vittella

Sustainable insect management is a need of recent area. Safe pest management strategies, biological suppression is considered as an effective, environmentally non-degrading, economically viable and socially acceptable method of pest management (Singh, 2001). Among the various biological control agents, Trichogramma egg parasitoids are being utilized for managing several Lepidoptera pests management as it is very effective. It has been reported that $T$. chllonis has the distinction of being the highest produced and most utilized biocontrol agent (Brar et al., 2000). T. chilonis releases at the rate of 50,000/ha during the active egg-laying period hold promise against a number of lepidopteran insect-pests (Table 2). 
Under laboratory conditions $T$. brasiliensis also parasitize eggs of $E$. vittella to the extent of 64 but when released under field conditions at Parbhani (Maharashtra) proved less efficient (Rao et al., 1978). It could be because of the unfavorable condition but it may be utilize as an effective control measure with certain standardization.

It is all known that neem has insecticidal property. Multi neem (Azadirecta indica) and NSKE (Neem Seed Kernel Extract being used against shoot and fruit borer and jassid on okra and found that all the treatments significantly reduced fruit infestation percentage and increased the yield of okra(Ansari et al.,2008). In an IPM trial in Punjab and Gujarat, the yield recorded was $11.9,13.7,15.7$ and $4.4 \mathrm{t} / \mathrm{ha}$ and 12.1, 18.6, 19.7 and 8.6 t/ha, respectively in $T$. chilonisalone, $T$. chilonis with five insecticide sprays, T. chilonis with 7 spray and in control plots (Anonymous, 1993).

In conclusion, insecticide resistance is defense mechanism of insect to overcome the effect of insecticide. It is the causes of indiscriminate and repeated use of a particular insecticide. In order to overcome the problem it is always advisable to use the combination of insecticide rather than a single one. One step ahead, it is always desirable to use integrated management strategy to overcome the resistance problem as bio control agent are very effective against Earias vittella.

\section{References}

Ananthkrishnan, T. N., (1999), Insects and host specificity (cd.) (Madras Loyola College). Pp 1-4.

Anonymous, 2011, www.indiastat.com.

Ansari, N. M. S., Ali H. And Ahmad T., 2008, Efficacy of multineem and NSKE with insecticides for management of Amrasca biguttula biguttula and Earias vittella on okra. Annals of Plant Protection Sciences, 16 (1): 17-20.

Bhargava, K.K., Sharma, H.C. And Kaul, C. L., 2001, Bioefficacy of insecticides against okra jassids and fruit borer. Pest Management and Economic Zoology, 9 (2): 193-195.

Bheemanna, M., Patil, B. V., Hanchinal, S. G., Hosamani, A. C. And Kengegowda, 2005, Bio- efficacy of Emamectin benzoate (Proclaim) 5\% SG against okra fruit borers. Pestology, 29(2):14-16.

Brar, J. S., Bhalla, J. S. And Singh, H., 1994, Chemical control of E. vittella in okra. Journal of Insect Sciences, 5: 225-226.

Brar, K. S., Khosla, S. S. And Sekhon, B. S., 2000, Host searching capacity of laboratory reared and, field corrected populations of Trichogramma chilonis Ishii. Journal of Biological Control, 14(2): 29-33.

Cheng, E. Y., Kao, C. H. And Chiu, C. S., 1992, Resistance, cross-resistance and chemical control of diamondback moth in Taiwan: Recent developments. In: Talekar, N. S. (Eds.), Diamondback Moth and Other Crucifer Pests: Proc. II Intl.Workshop, AVRDC, Tainan, Taiwan, pp. 465-475.

Das, S., Ray, S. And Chatterjee, M. L., 2000, Efficacy of some new insecticides against Earias vittella (F.) infestation on okra and cost benefit analysis. Pest Management and Economic Zoology, 8 (1): 99-101.

Ghosh, 2001, genetically engineered crops in India with special reference to $\mathrm{Bt}$ cotton. IPM Mitr., 2: 8-21.

Gupta, S.C. And Mishra, A. K., 2006, Management of okra shoot and fruit borer, Earias vittella Fab. Through biorational insecticides. Pesticide Research Journal, 18(1): 33-34.

Hirano, M. H., Takeda and Satoh, H., 1993, a simple method for monitoring pyrethroid susceptibility in field colonies of $E$. insulana and $P$. gossypiella. J. Pesti. Sci., 18 (3): 239-243.

Hiremath, R. G. (2004), Host preference of spotted bollworm. Earias spp. (Lepidoptera: Noctuidae). Entomon., 9 (3) : 185-188.

Hung, C. F., Kao, C. H., Liu, C. C., Lin, J. G. And Sun, C. N., 1990, Detoxifying enzymes of selected insect species with 
chewing and sucking habits. J. Econ. Entomol.,83: 361-365.

Hussain, M. A. And Mathur, U. B., 1924, some parasites of the cotton bollworms (Earias insulana and E. fabia) in the Punjab. Report of the proceedings 5th Entomological meeting Pusa, 34-52.

Kitturmath, M. S., 2008, Investigations on insecticide resistance in Spodoptera litura Fab. (Lepidotera: Noctuidae). Ph. D. Thesis, University of AgriculturalSciences, Bangalore, Karnataka.

Konar, A. And Rai, L., 1990, Efficacy of some insecticides against shoot and fruit borers (Earias vittella Fab. and E. insulana Boisd.) of okra (Abelmoschus esculentus L. Moench). Environment and Ecology, 8: 410-413.

Kranthi, K. R., Jadhav, D. R., Kranthi, S., Wanjari, R. R., Ali, S. and Russell. D., 2002, Insecticide resistance in five major insect pests of cotton in India. Crop Protection, 21: 449-460.

Li, T. W., Gao, X. W., Zheng, B. Z., Zhu, S. X. And Si, S.Y., 1998, A study on carboxylesterase activity in insecticide resistant and susceptible populations of diamondback moth, Plutella xylostella from different regions. Acta Entomologica Sinica, 41: 26 - 33 .

Maa, C. J. W., Tseng, W. P. And Huan, I. C., 1990, Preliminary characterization of the larval esterases and the isozymes of diamondback moth, Plutella xylostella (L.).Bull. Insect Zool. Acad. Sinica., 29:181 - 194.

Mahapatro, G. K. And Gupta, G. P., 1998, Pesticide induced resurgence. Pestology, 22:14-20.

Martin, T., Ochou, O. G., Vaissayre, M. And Fournier, D., 2003, Oxidases responsible for resistance to pyrethroids sensitize Helicoverpa armigera (Hubner) and Earias vittella to triazophos in West Africa. Insect Biochem. Mol. Biol., 33: 883-887.

Manjunath, T. M., 1974, Evaluation of the effect of two insecticidal schedules on important pest of hybrid-4 cotton and their natural enemies. Msc. (agri) thesis Gujarat agricultural university, Anand, pp. 66.

Moore, A., Tabashnik, B. E. And Stark, J. D., 1989, Leg autotomy: a novel mechanism of protection against insecticidal poisoning in Diamondback moth (Lepidoptera: Plutellidae). J. Econ. Entomol, 82: 1295 - 1298.

Motoyama, N., Suganuma, T. And Maekoshi, Y., 1992, Biochemical and Physiological characteristics of insecticide resistance in Diamondback moth. In: Talekar (Eds.), Diamondback Moth and other Crucifer Pests: Proc. II Internl. Workshop, Tainan, Taiwan. pp. 411-418.

Mushtaq Ahmad and Iqbal Arif, 2009, Resistance of Pakistani field population of spotted bollworm Earias vittella (Lepidoptera: Noctuidae) to pyrethroid, organophosphorous and new chemical insecticides. Pest Manag. Sci., 65:433439.

Maninder, Varma, G. C. And Sekhon, B. S., 1983, New hosts and first record of Trichogramma achaeae Nagaraja and Nagarakatti (Trichogrammatidae: Hymenoptera) from the Punjab. Bull. Entomol, 24: 36.

Nagan Gouda, A. And Thontadarya, T. S., 1984, Incidences of natural enemies of Heliothis armigera Hubner and Earias spp. on okra used as trap crop in the management of cotton bollworms. Curr. Res., 13: 56-57.

Papal, S. A. And Bharpoda, T. M., 2010, Bioefficacy of various synthetic insecticides against fruit borer, Earias vittella (Fabricius) in okra. Current Biotica, 4 (2): 256-260.

Papal, S.A. And Bharpoda, T.M., 2009, Evaluation of different insecticides against shoot and fruit borer, Earias vittella (Fabricius) on okra grown for seed purpose. Karnataka Journal of Agricultural Sciences, 22 (3): 707-709. 
Raj, S. 1985, Chemical control of bhendi pests. Indian Journal of Entomology, 47 (2): 173-178.

Rao, A. K, Sarkate, M. B., Deshpande, A. D. And Thombre, V. T., 1978, Studies on the mass multiplication, field releases and recovery of Trichogramma brasiliensis Ashm., an egg parasite of cotton bollworms at Parbhani] ournal of Maharashtra Agricultural Sciences,3(2): 103-106.

Saini, R. K., Chopra, N. P. And Verma, A. N., 1989, Development of insecticide resistance and cross resistance in fenvalerate and cypermethrin selected strains of E. vitella. Pesticide Sci., 25 (3): 289-295.

Sarkar, B. B. And Nath, S. C., 1989, Field evaluation of various insecticides against fruit borer (Earias vittella F.) and effect on yield of lady's finger seed. Pestology, 13(4): 19-21.

Satpute, N. S., Deshmukh, S. D., Rao, N. G. V., Tikar, S. N., Moharil, M. P. And Nimbalkar, S. A., 2003, Native Insecticide Resistance in Spotted Bollworm, Earias vitella (Fabricius) in Western Vidarbha Region of India.Resist. Pest Mana.Newsl, 13(1): 9-11.

Scott, J. G., 1991, Insecticide resistance in insects. In: Pimental, D. (Ed.), Handbook of Pest Managt. Agric., CRC Press, Boca Raton, 2: 663.

Sharma, R. P. And Bhati, K. K., 2008, Bioefficacy of some newer insecticides against Earias vitella infesting okra. Pestology, 32(10): 47-49.

Singh, S. P., 2001, Biological control in horticultural crops. Indian Horticulture, 45:54-61.
Sinha, S.R., Vishwa Nath and Rai Singh, 2009, Management of Earias vittella through new insecticide schedules. Annals of Plant Protection Sciences, 17 (1): 242243.

Soderlund, D. M., 1997, In: Sjut, V. (Ed.), Molecular Mechanisms of Resistance to Agrochemicals. Springer Verlag, Berlin/Heidelberg, pp. 21-56.

Supriya Biswas, Das, K. And Ghosh, S. K., 2009, Field efficacy of different insecticides and neem against Earias vittela (Fab.) on okra.J. ent. Res., 33(4): 331-333.

Tang Zhen Hua Tao Li Ming, 2008, Molecular mechanism of action of novel diamide insecticides on ryanodine receptor. [Chinese]. Acta Entomologica Sinica, 51 (6): 646-651.

Verma, G. S., 1985, Response of chemicals to control spotted bollworm in okra. Indian Journal of Entomology, 47(3): 357-358

Vontas, J. G., Small, G. J., Nikou, D. C., Ranson, H. And Hemingway, J., 2002, Purification, molecular cloning and heterologous expression of a glutathione S-transferase involved in insecticide resistance from the spotted bollworm, Earias vittella, Biochem. J., 362: 329337.

Wilkinson, C. F., 1983, Role of mixed function oxidase in insecticide resistance. In: Georghiou, G. P. and Saito, Y. (Eds.), Pest Resistance to Pesticides, Plenum press, New York, pp. 175-206.

Kranthi, K. R., 2005, Insecticide Resistance; Monitoring mechanism and Management Manual. CICR Tech. Bull., 143: 155pp, ICAR.

\section{How to cite this article:}

Das Ratan, Deb Prahlad, Himanshu Pandey and Moutushi Sarkar. 2017. Insecticidal Resistance of Okra Fruit Borer (Earias vittella) and its Management. Int.J.Curr.Microbiol.App.Sci. 6(6): 2932-2941. doi: https://doi.org/10.20546/ijcmas.2017.606.348 